\title{
Pengembangan Multimedia Pembelajaran Interaktif Pada Mata Pelajaran Pengolahan Citra Digital di Sekolah Menengah Kejuruan Negeri 8 Semarang
}

\author{
Yuli Sintya Maharani22, Nunuk Suryani23, Deny Tri Ardianto24 \\ yuli.sintya@gmail.com
}

\begin{abstract}
This research aims to; (1) describe the needs of subjects Digital Image Processing class XI Multimedia at SMK N 8 Semarang, (2) development of Interactive Digital Image Processing class XI Multimedia at SMK N 8 Semarang, and (3) Measurement of multimedia effectiveness Product development on image processing subjects Digital class $\mathrm{XI}$ Multimedia at SMK N 8 Semarang. This research was research and development, which referred to the ADDIE model. The Learning interctive multimedia was developed through five stages, the developmental steps begun by analyzing the requirements, design, manufacturing, implementation, and evaluation. The process assesses the feasibility of learning media by providing questionnaires to media experts, material experts, and test respondents (students). Data questionnaire is then processed to determine the feasibility of media. The results of this study is interactive multimedia learning products with Adobe Flash application base. This can be seen from the validation of material experts with an average of 4.51 and has a very good category. Validation of media experts with an average of 4.59 is a very good category. According to the students, this multimedia is very good with an average of 4.61. The result of this research showed that the developed media had been fulfilled the requisites and worthy of being a medium of learning. The result of $t$-test by using paired sample $t$-test obtained result that on $\alpha=5 \%$ with $D K=\left\{t \mid t \leq-t_{0.025 ; 33}=-2,03\right.$ or $\left.t \geq t_{0.025 ; 33}=2,03\right\}$ and $t_{\text {obs }}=-7,29$, maka $-t_{\text {obs }}=-7.297 \geq-t_{\text {table }}=-2.034$. And was obtained value Sig. (2-tailed) $=0.000<0.05$, therefore, it can be concluded that both groups have unequal achievement. The experimental class has an average of 85.41 while the control class has an average of 71.29. So it can be concluded learning multimedia is effective to be used in the learning activity and can improve student achievement.
\end{abstract}

Keyword: Development; Interactive Learning Multimedia; Digital Image Processing

\footnotetext{
22 Mahasiswa Magister Teknologi Pendidikan Universitas Sebelas Maret Surakarta

23 Dosen Universitas Sebelas Maret Surakarta

24 Dosen Universitas Sebelas Maret Surakarta
} 


\section{PENDAHULUAN}

K ualitas pendidikan bergantung dari proses pembelajaran yang terjadi antara guru dengan murid secara efektif. Hal tersebut berarti dalam proses pembelajaran dapat terselenggara secara lancar, terarah, dan sesuai dengan tujuan pembelajaran. Proses pembelajaran memiliki banyak faktor yang sangat berpengaruh di dalamnya, diantaranya faktor pendidik, fasilitas atau sarana dan prasarana, lingkungan belajar, kurikulum yang digunakan, input dari siswa tersebut sendiri. Hasil wawancara dengan Bapak Yemi selaku Ketua Kompetensi Keahlian Multimedia dan Bapak Baskoro Aji Nugroho, S.Pd selaku guru mata pelajaran Pengolahan Citra Digital (PCD) pada tanggal 27 Januari 2017 didapatkan data bahwa Saat ini SMK Negeri 8 Semarang mempunyai empat jurusan yaitu Pekerjaan Sosial (Peksos), Rekayasa Perangkat Lunak (RPL), Multimedia (MM) dan Teknik Komputer dan Jaringan (TKJ).Khususnya pada jurusan multimedia perolehan nilai siswa jurusan multimedia pada semester ganjil untuk mata pelajaran pengolahan citra digital khususnya untuk nilai teori masih banyak siswa yang memperoleh nilai dibawah 75 yaitu standar KKM. Bobot nilai yang ditetapkan di SMKN 8 Semarang yaitu $70 \%$ untuk nilai Praktek dan 30\% untuk Teori.

Permasalahan yang terjadi dikelas siswa lebih cenderung fokus pada praktek dibandingkan teori. Disamping permasalahan tersebut, guru kesulitan dalam mencari media yang cocok untuk siswa dalam mendalami teori yang diberikan. Saat ini metode yang digunakan guru dalam mengajar masih menggunakan metode ceramah dengan buku pedoman e-book. Kurangnya variasi media yang digunakan dalam pembelajaran menjadikan siswa kurang aktif selama kegiatan belajar mengajar berlangsung, dalam penerapannya media ebook terbatas hanya pada konten teks dan gambar sehingga tampilan kurang menarik dan tidak mewakili semua materi pembelajaran yang akan diajarkan, hal tersebut akan mempengaruhi nilai atau prestasi belajar siswa yang menurun.

Permasalahan tersebut memberikan ide kepada peneliti untuk membantu guru dalam mengembangkan suatu media pembelajaran berbasis teknologi yang biasa disebut multimedia pembelajaran interaktif menggunakan program Adobe Flash. Multimedia pembelajaran interaktif diharapkan dapat mengatasi keterbatasan pengalaman siswa dan keterbatasan ruangan kelas, menanamkan konsep dasar yang benar, konkret dan realistis, menimbulkan keinginan dan minat baru, membangkitkan motivasi belajar siswa. Multimedia pembelajaran interaktif diharapkan dapat menjadi alat bantu guru dalam kegiatan pembelajaran PCD di SMKN 8 Semarang, sehingga siswa tidak jenuh dalam menerima materi pembelajaran, sehingga dapat menciptakan proses pembelajaran yang menarik dan menyenangkan. Penelitian ini bertujuan untuk ; (1) mengetahui kebutuhan guru dan siswa dalam pelaksanaan pembelajaran pada mata pelajaran pengolahan citra digital kelas XI Multimedia di SMK N 8 Semarang? (2) bagaimana mengembangkan multimedia pembelajaran interaktif pada mata pelajaran pengolahan citra digital kelas XI Multimedia di SMK N 8 Semarang ? dan (3) bagaimana keefektifan produk pengembangan multimedia pembelajaran interaktif pada mata pelajaran pengolahan citra digital kelas XI Multimedia di SMK N 8 Semarang bagaimana pengembangan multimedia pembelajaran interaktif pada mata pelajaran pengolahan citra digital kelas XI Multimedia di SMK N 8 Semarang ?

Pengembangan adalah proses penerjemahan secara spesifik desain ke dalam bentuk fisik, benda yang dapat diraba dan untuk menerima pesan. Di dalam kawasan teknologi pendidikan, domain pengembangan didasari oleh teori desain dan mencakup berbagai variasi teknologi yang diterapkan dalam pembelajaran. Kawasan pengembangan dapat dikategorikan dalam desain teknologi cetak, teknologi audiovisual, teknologi berasaskan komputer dan teknologi terpadu (Seel \& Richey, 1994). Pada penelitian ini yang dimaksud dengan pengembangan adalah pembuatan dan penggunaan 
multimedia pembelajaran interaktif untuk sarana belajar mengajar agar proses belajar mengajar menarik minat siswa.

Media adalah segala sesuatu yang dapat digunakan untuk menyalurkan pesan dari pengirim ke penerima sehingga dapat merangsang pikiran, perasaan perhatian dan minat serta perhatian siswa sedemikian rupa sehingga proses belajar terjadi (Sadiman, dkk., 2012). Rachman dalam Kustiono (2010) mengemukakan, media pembelajaran berfungsi mengatasi keterbatasan pengalaman siswa dan keterbatasan ruangan kelas; memungkinkan interaksi langsung antara siswa dengan lingkungan; menghasilkan keseragaman pengamatan; menanamkan konsep dasar yang benar, konkret dan realistis; menimbulkan keinginan dan minat baru; membangkitkan motivasi belajar siswa; memberikan pengalaman yang integral dari yang konkret ke yang abstrak. Oleh karena itu, media pembelajaran haruslah dipersiapkan sebaik-baiknya, agar penyampaian isi pesan dalam materi pembelajaran dapat mudah dipahami oleh siswa dan dapat meningkatkan hasil belajar siswa. Selain itu media pembelajaran diharapkan dapat meningkatkan motivasi siswa, sehingga siswa lebih aktif dalam proses kegiatan belajar mengajar.

Menurut Smaldino, dkk (2008) mengemukakan bahwa multimedia diartikan sebagai penggunaan berbagai jenis media secara berurutan maupun simultan untuk menyajikan suatu informasi. Multimedia tidak harus menggunakan alat-alat canggih. Pendapat yang sama juga dikemukakan oleh Helzafah (2004) yang mengatakan bahwa multimedia digunakan untuk mendeskripsikan penggunaan berbagai media secara terpadu dalam menyajikan atau mengajarkan suatu topic mata pelajaran (Anitah, 2009). Interaktif menurut Sutopo (2012) dapat diartikan user atau pengguna dapat memilih apa yang akan dikerjakan selanjutnya, bertanya dan mendapatkan jawaban yang mempengaruhi komputer untuk mengerjakan fungsi selanjutnya. Menurut Warsita (2008), multimedia pembelajaran interaktif memiliki beberapa kelebihan, yaitu: fleksibel, self-pasing, content rich, interaktif, dan individual.

Dari uraian di atas dapat disimpulkan bahwa Multimedia Pembelajaran Interaktif adalah segala sesuatu baik hardware maupun software yang mampu mengkondisikan siswa berinteraksi secara aktif dan mandiri dengan seperangkat pesan-pesan pembelajaran yang berkemas secara harmonis baik teks maupun hyperteks, terpadu dengan gambar-gambar, suara video/film dan animasi untuk kepentingan pencapaian tujuan-tujuan pembelajaran tertentu. Berdasarkan definisi-definisi tersebut maka peneliti menyimpulkan bahwa Multimedia Pembelajaran Interaktif adalah perpaduan antara berbagai media berupa teks, gambar, grafik, sound, animasi, video, yang dikemas dengan tampilan yang menarik untuk membangkitkan minat dan motivasi siswa agar terjadi interaksi anatara guru dan siswa secara interaktif dan memudahkan guru dalam memberikan solusi dalam kegiatan pembelajaran agar tujuan pembelajaran tercapai dengan maksimal.

Pengolahan Citra Digital adalah salah satu mata pelajaran wajib dasar program keahlian Teknik Komputer dan Informatika (TKI). Berdasarkan struktur kurikulum mata pelajaran Pengolahan Citra Digital-2 disampaikan di kelas XI semester 2, 4 jam pelajaran per minggu. Untuk semester 2 topik materi pembelajaran menekankan pada pengenalan citra vektor danpengolahan citra bitmap. Dalam desain komunikasi visual, teks maupun obyek grafis serta warna memainkan peranan sangat penting dalam keberhasilan suatu bentuk seni komunikasi grafis. teks maupun obyek grafis serta warna bukan lagi sebagai pelengkap statement visual, tetapi sudah menjadi sajian utama komunikasi grafis yang berbentuk buku, katalog atau brosur. Sehingga sangat penting untuk mempelajari teks maupun obyek grafis serta warnapada perancangan desain grafis yang mengandung unsure estetika. Citra bitmap pengembangan karya grafis sesuai dengan kaidah-kaidah pembuatan karya grafis. 


\section{METODE PENELITIAN}

Penelitian ini dilaksanakan di SMK N 8 Semarang yang beralamat di Jalan Pandanaran II No.12 Mugas sari, Semarang. Penelitian ini menggunakan metode penelitian Research and Development (penelitian dan pengembangan) yang dapat didefinisikan sebagai metode penelitian untuk menghasilkan sebuah produk bersifat procedural (Sugiyono, 2008). Dalam penelitian ini, peneliti memilih model pengembangan ADDIE yang mencakup aspek Analyze (analisis), Design (perancangan), Development (pengembangan), Implementation (penerapan), dan Evaluation (penilaian) yang berorientasi pada produk (Molenda, 2008) dalam Anitah (2009). Alasan peneliti menggunakan model pengembangan, dikarenakan memiliki keunggulan yaitu dilihat dari prosedur kerjanya yang sistematik, yakni pada setiap langkah yang akan dilalui selalu mengacu pada langkah sebelumnya yang sudah diperbaiki sehingga diperoleh produk yang efektif.

Pada pelaksanaan dan penerapannya, Model ADDIE adalah: (1) Analysis yang dapat diartikan sebagai analisis kebutuhan awal pada siswa untuk menentukan atau mendesain awal materi pembelajaran dimana nantinya sebagai kebutuhan Pembuatan Program Multimedia Pembelajaran, (2) Design dapat diartikan sebagai desain awal produk berdasarkan analisis kebutuhan dalam materi pengukuran waktu dan sudut pada siswa kelas XI Multimedia, (3) Development yang dapat diartikan sebagai mem-produksi program pembelajaran multimedia pembelajaran interaktif, (4) Implementation diartikan sebagai implementasi atau proses pengujian produk multimedia pembelajaran interaktif mata pelajaran PCD, (5) Evaluation yang diartikan sebagai Evaluasi program multimedia pembelajaran interaktif mata pelajaran $P C D$, yang telah dihasilkan dan di uji cobakan.

Subjek uji coba dalam penelitian adalah 34 orang siswa kelas XI Multimedia 3 (kelas eksperimen) dan 34 orang siswa kelas XI Multimedia 2 (kelas kontrol). Instrumen pengumpulan data yang digunakan yaitu angket dan lembar observasi pengamatan. Angket digunakan untuk mengevaluasi terkait media yang diberikan kepada ahli media untuk mengetahui penilaian ahli media terhadap media yang dikembangkan, dan angket terkait materi diberikan kepada ahli materi untuk mengetahui penilaian ahli materi terhadap materi yang sudah dikembangkan. Lembar observasi pengamatan digunakan untuk menelusuri minat belajar siswa. Teknik analisis data yang digunakan yaitu analisis statistik deskriptif. Analisis statistik deskriptif digunakan untuk menganalisis dan mendeskripsikan data yang telah terkumpul berdasarkan lembar observasi pengamatan yang dilakukan oleh guru. Data kuantitatif dari hasil angket validasi kemudian diubah menjadi data kualitatif menggunakan skala lima, yaitu penskoran dari angka satu sampai dengan lima.

Tabel 1. Konversi Data Kuantitatif Ke Dalam Data Kualitatif

\begin{tabular}{ccc}
\hline Interval Skor & Nilai & Kategori \\
\hline$X>4.21$ & 5 & Sangat baik \\
$3.40<X \leq 4.21$ & 4 & Baik \\
$2.60<X \leq 3.40$ & 3 & Cukup \\
$1.79<X \leq 2.60$ & 2 & Kurang \\
$X \leq 1.79$ & 1 & Sangat kurang \\
\hline
\end{tabular}




\section{HASIL DAN PEMBAHASAN}

Uji coba penelitian dan pengembangan ini dilaksanakan di Sekolah Menengah Kejuruan (SMK) Negeri 8 Semarang yang bertempat di jalan Pandanaran II No. 12 Mugassari Semarang Selatan, Kota Semarang. Guru mengalami kesulitan dalam menyampaikan materi pembelajaran khususnya untuk teori karena guru sulit untuk mencari alat bantu atau media yang tepat untuk menyampaikan materi pembelajaran agar siswa ikut aktif dalam KBM. Salah satunya pada mata pelajaran Pengolahan Citra Digital dimana pada mata pelajaran ini lebih menekankan siswanya untuk kerja secara praktik yaitu dengan tugas akhir menghasilkan sebuah produk.

Nilai yang nantinya akan diperoleh siswa pada nilai akhir yaitu $70 \%$ bobot praktek dan $30 \%$ bobot teori. Sehingga teori biasanya disampaikan pada awal pembelajaran yaitu 2 minggu dengan jumlah 8 jam pembelajaran. Selain itu media untuk menyampaikan materi hanya terbatas pada buku siswa yang beratus-ratus halaman sehingga siswa cenderung malas untuk membaca. Hal ini lah yang membuat guru kesulitan untuk mencari media pembelajaran yang membangkitkan motivasi siswa untuk belajar disekolah maupun dirumah. Hasil pengamatan yang dilakukan peneliti di SMKN 8 Semarang diperoleh hasil data yaitu sarana dan prasarana yang dimiliki sekolah sangat memadai seperti ruang kelas yang dilengkapi dengan LCD, komputer/laptop dan memiliki ruang laboratorium komputer sebanyak 8 ruangan yang biasa digunakan siswa untuk mata pelajaran praktek.

Berdasarkan analisis kebutuhan yang dilaksanakan oleh peneliti dapat disimpulkan bahwa guru mengalami kesulitan dalam mencari media yang cocok diterapkan untuk belajar siswa khususnya untuk mata pelajaran yang berhubungan dengan teori dasar yang seharusnya siswa mampu menguasai teori tersebut sebelum siswa melakukan praktik. Salah satunya pada mata pelajaran pengolahan citra digital di kelas XI Multimedia.

\section{Tahap Desain}

Pembuatan desain didasarkan pada hasil observasi awal dalam kegiatan analisis kebutuhan yang meliputi pemilihan dan pengumpulan materi atau konten dalam bentuk teks dan gambari pendukung yang dapat membangun motivasi siswa dalam belajar citra vektor pada mata pelajaran PCD yang akan digunakan dalam multimedia pembelajaran interaktif, penyusunan flowchart, penyusunan Garis Besar Isi Media, penyusunan naskah dan desain tampilan. Berikut ini merupakan tampilan flowchart yang digunakan untuk membuat multimedia pembelajaran interaktif pada mata pelajaran pengolahan citra digital: 


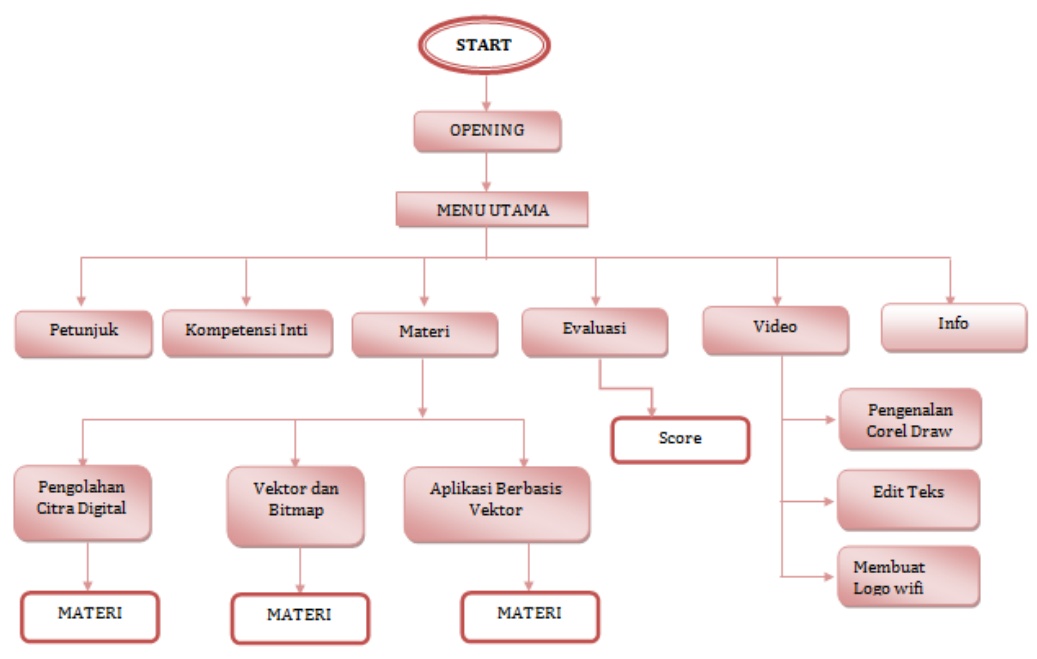

Bagan 1. Desain Flowchart Multimedia Pembelajaran Interaktif

Tahap desain yaitu desain produk dalam penelitian ini adalah naskah produk dan desain produk media pembelajaran. Peneliti membuat naskah terdiri dari peta konsep, peta kompetensi, flowchart, garis besar isi media, dan isi naskah tersebut setelah naskah selesai kemudian dikembangkan menjadi produk awal media pembelajaran yang nanti akan dikonsultasikan kepada ahli atau pakar media dan ahli materi untuk divalidasi.

\section{Tahap Pengembangan}

Pada tahap ini, peneliti melanjutkan pembuatan produk berdasarkan storyboard dan desain yang telah dibuat. multimedia pembelajaran interaktif mata pelajaran PCD ini dikembangkan menggunakan software Adobe Flash. Hal-hal yang peneliti pertimbangkan untuk mengembangkan multimedia ini adalah ketersediaan materi. Peran guru dalam penyusunan media hanyalah sebagai pengguna saja, bukan sekaligus sebagai pengembang. Multimedia ini hanya sebagai pelengkap atau sarana untuk belajar bukan sebagai pengganti guru dikelas. Penggunaan multimedia pembelajaran interaktif ini sangat mudah. Program yang sudah di jadikan file aplikasi (.exe) di simpan ke dalam komputer kemudian siswa tinggal klik dua kali langsung muncul tampilan MPI. Tombol-tombol navigasi juga tersedia dalam program tersebut. Seperti tombol menu, sound, next, back, dan tombol keluar. Pada multimedia pembelajaran interaktif berisi tampilan Opening, petunjuk penggunaan, deskripsi kompetensi, profil pengembang, tombol bantuan, materi, latihan soal dan sumber materi.

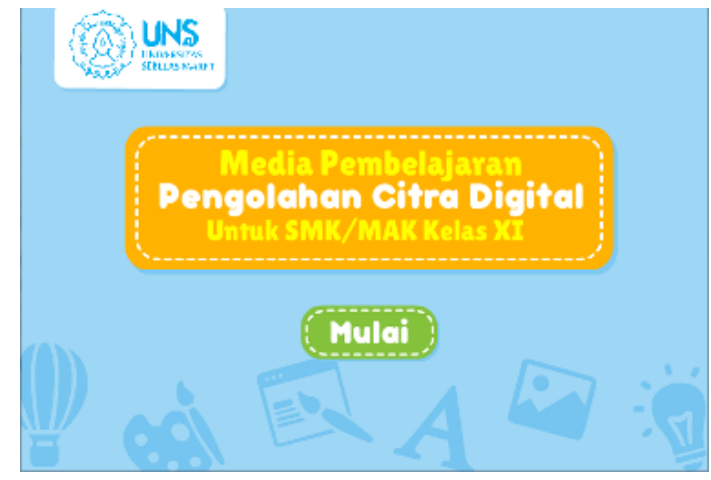

Gambar 1. Tampilan Opening MPI

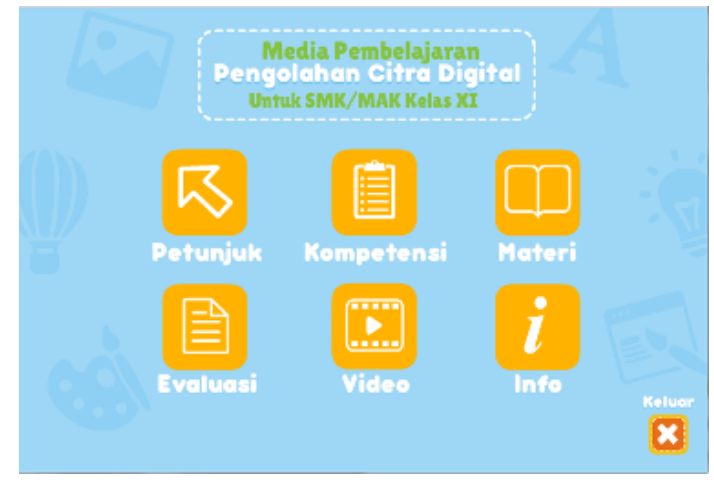

Gambar 2. Tampilan Menu Utama 


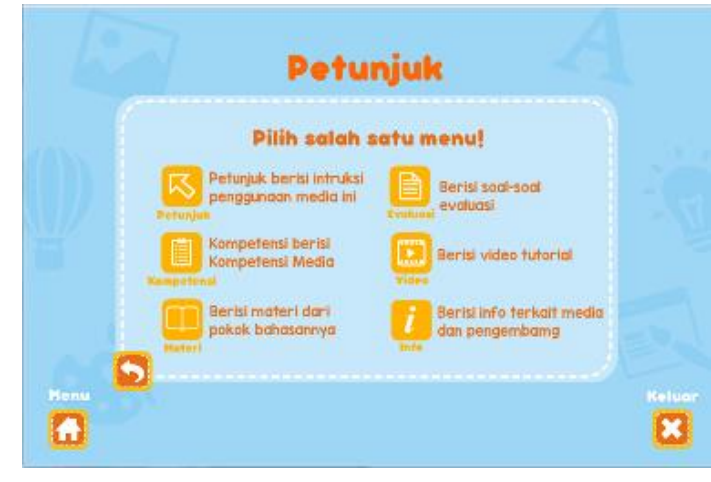

Gambar 3. Tampilan Menu Petunjuk

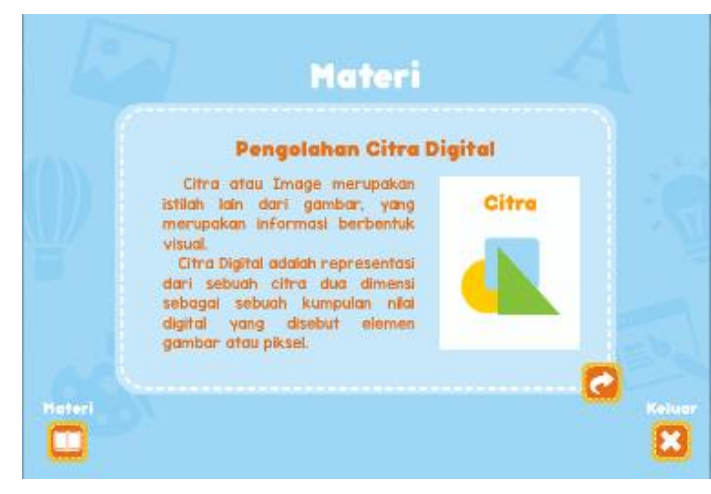

Gambar 5. Tampilan Menu Materi

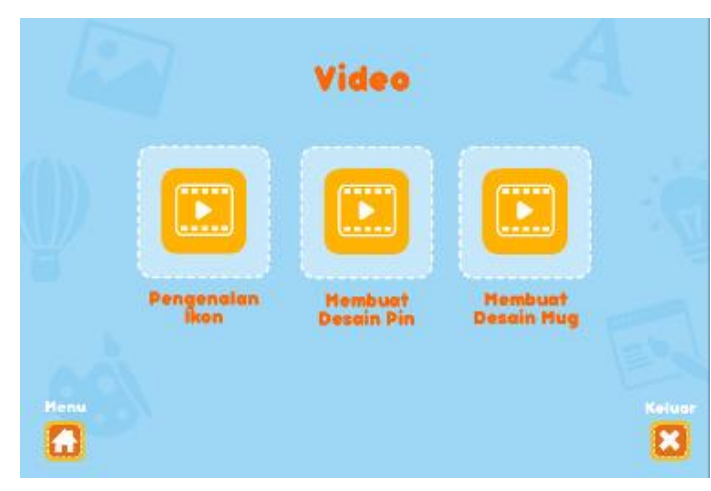

Gambar 7. Tampilan Menu Evaluasi

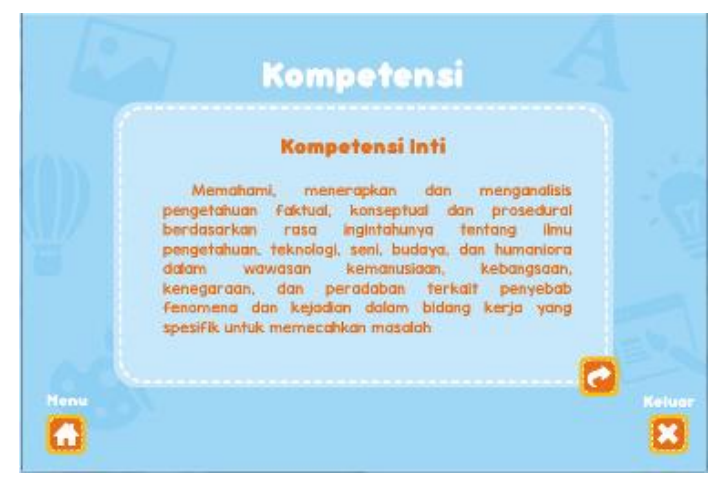

Gambar 4. Tampilan Menu Kompetensi

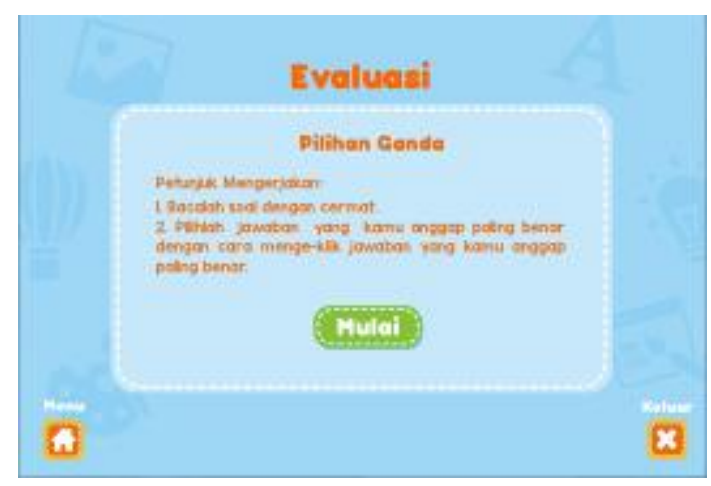

Gambar 6. Tampilan Menu Evaluasi

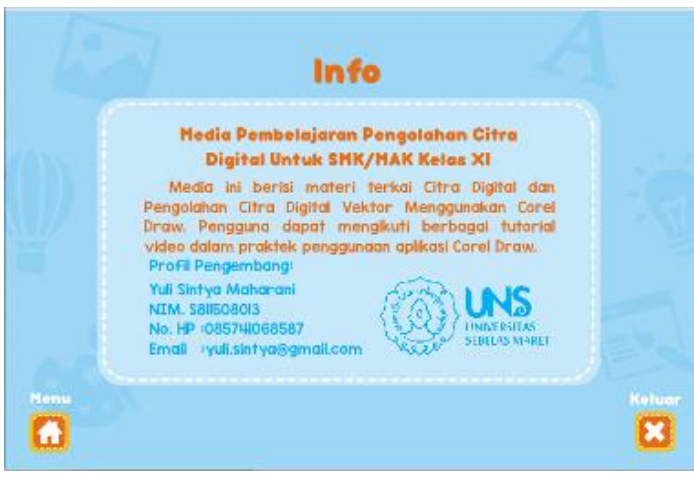

Gambar 8. Tampilan Menu Video

Pada tahap pasca produksi, program multimedia pembelajaran interaktif di teliti kembali dari segi konten dan tampilan. Setelah itu program dibakar kedalam kepingan CD. File multimedia pembelakaran interaktif yang dibakar dalam CD berupa file aplikasi .exe dan .swf. Pada tahap ini terdapat proses validasi dilakukan oleh beberapa ahli sebelum peneliti menerapkan langsung pada proses pembelajaran di kelas. Validasi program dilakukan oleh ahli materi dan ahli media. 
Berikut ini adalah hasil penilaian Multimedia Pembelajaran Interaktif oleh ahli materi dan ahli media, diperoleh hasil validasi sebagai berikut:

Tabel 1. Hasil Validasi Ahli Materi

\begin{tabular}{|c|c|c|c|c|c|c|c|c|c|c|c|c|c|c|c|c|c|c|c|c|c|c|c|c|c|c|}
\hline \multirow{2}{*}{ NO } & \multirow{2}{*}{ NAMA AHLI MATERI } & \multicolumn{14}{|c|}{ ASPEK PEMBELAJARAN } & \multicolumn{11}{|c|}{ ASPEK MATERI } \\
\hline & & 1 & 2 & 3 & 4 & 5 & 6 & 7 & 8 & 9 & 10 & 11 & 12 & 131 & 14 & 1 & 2 & 3 & 4 & 5 & 6 & 78 & 9 & 10 & 11 & 12 \\
\hline 1. & Baskoro Aji Nu & 5 & 5 & 5 & 5 & 5 & 5 & 4 & 4 & 4 & 5 & 5 & 5 & 5 & 4 & 5 & 5 & 4 & 5 & 5 & 5 & 45 & 5 & 5 & 5 & 4 \\
\hline$?$ & Yemi M. Arbi, S.Pd & 5 & 4 & 5 & 4 & 4 & 4 & 5 & 3 & 3 & 4 & 4 & 5 & 4 & 3 & 5 & 4 & 4 & 5 & 4 & 4 & 45 & 5 & 5 & 5 & 4 \\
\hline & Rata-Rata & \multicolumn{14}{|c|}{4,39} & \multicolumn{11}{|c|}{4,63} \\
\hline & Rata-Rata Total & & & & & & & & & & & & & & & & & & & & & & & & & \\
\hline
\end{tabular}

Berdasarkan hasil angket validasi dapat disimpulkan bahwa konten Multimedia Pembelajaran Interaktif diperoleh hasil 4,39 untuk aspek pembelajaran dengan keterangan sangat baik. Sedangkan untuk aspek materi diperoleh hasil 4,63 dengan keterangan sangat baik. Dapat disimpulkan bahwa materi multimedia pembelajaran interaktraktif pada mata pelajaran PCD sangat baik dan layak untuk digunakan sebagai media pelajaran. media:

Setelah mencoba program media pembelajaran interaktif ini diperoleh hasil validasi dari ahli

Tabel 2. Hasil Validasi Ahli Media

\begin{tabular}{|c|c|c|c|c|c|c|c|c|c|c|c|c|c|c|c|c|c|c|c|c|c|c|}
\hline \multirow{2}{*}{ NO } & \multirow{2}{*}{ NAMA AHLI MEDIA } & \multicolumn{6}{|c|}{ Aspek Navigasi } & \multicolumn{9}{|c|}{ Aspek Tampilan } & \multicolumn{4}{|c|}{ Aspek Daya Tahan } & \multirow{2}{*}{ Total } & \multirow{2}{*}{ rata-rata } \\
\hline & & 1 & 2 & 3 & 4 & 5 & 6 & 1 & 2 & 3 & 4 & \begin{tabular}{l|l}
5 & 6
\end{tabular} & 7 & 8 & 9 & 10 & 1 & 2 & 3 & 4 & & \\
\hline 1 & Tri Astuti, M.Pd & 5 & 5 & 5 & 5 & 5 & 5 & 5 & 4 & 4 & 5 & \begin{tabular}{l|l}
4 & 4
\end{tabular} & 5 & 5 & 4 & 5 & 4 & 5 & 5 & 4 & 93 & 4,65 \\
\hline 2 & Dr. Wardi, M.Pd & 4 & 5 & 4 & 5 & 5 & 5 & 3 & 4 & 4 & 4 & \begin{tabular}{l|l}
5 & 5 \\
\end{tabular} & 4 & 4 & 4 & 4 & 5 & 4 & 5 & 5 & 88 & 4,4 \\
\hline & Rata-Rata & & & 4,83 & & & & & & & & 4,30 & & & & & & 4,6 & & & & \\
\hline & Rata-Rata Total & & & & & & & & & & 4,59 & & & & & & & & & & & \\
\hline
\end{tabular}

Kesimpulan dari validasi ahli media 1 dan 2 yaitu multimedia pembelajaran interaktif mata pelajaran PCD dikatakan sangat baik dari Aspek Navigasi dengan nilai rata-rata 4,83 dan aspek Tampilan dengan nilai rata-rata 4,30 dengan kategori sangat baik. Aspek daya tahan program sangat baik dengan nilai rata-rata 4,63 . Sehingga multimedia pembelajaran interaktif mata pelajaran PCD sudah dinyatakan layak digunakan tanpa revisi dalam proses pembalajaran.

Validasi oleh Siswa dari Uji Coba Produk. Uji coba produk dilakukan untuk mengetahui apakah produk yang dikembangkan dapat bermanfaat bagi peningkatan mutu pembelajaran atau tidak. Uji coba produk yang dilakukan dalam penelitian ini ada 3 jenis yaitu uji coba lapangan awal (preliminary field test), uji coba lapangan utama (main field test), dan uji coba lapangan operasional (operational field test) (Borg \& Gall, 2007).

Uji coba ini dilakukan kepada 5 orang siswa. Peserta uji coba memberikan tanggapan terhadap produk yang dikembangkan. Pada tahap ini siswa menilai dari 2 aspek yaitu aspek motivasi dan aspek kemenarikan. Pada uji coba ini terdapat 15 orang siswa yang memberikan tanggapan dan penilaian terhadap produk yang dikembangkan. Pada tahap ini siswa menilai 3 komponen yaitu komponen isi 
atau materi, tampilan dan penyajian. Uji coba oprasional (Oprastional Field Test) dilakukan dengan melibatkan siswa yang lebih besar. Siswa yang diikut sertakan dalam uji coba ini adalah siswa kelas XI MM yaitu 34 orang siswa. Hasil penilaian oleh siswa ditampilkan dalam tabel berikut ini:

Tabel 3. Hasil kelayakan oleh siswa

\begin{tabular}{cccc}
\hline No. & Aspek Penilaian & Rata-Rata & Katagori \\
\hline 1. & Aspek Motivasi & 4,60 & Sangat Baik \\
2. & Aspek Kemenarikan & 4,69 & Sangat Baik \\
3. & Aspek Kemudahan & 4,57 & Sangat Baik \\
4. & Aspek Kemanfaatan & 4,57 & Sangat Baik \\
\hline
\end{tabular}

Berdasarkan tabel perhittungan pada keempat aspek diatas dapat disimpulkan bahwa berdasarkan aspek motivasi mendapatkan rata-rata 4,6 pada katagori sangat baik. Aspek kemenarikan dengan 4,69 dengan katagori sangat baik. Aspek kemudahan memperoleh rata-rata 4,57 dan aspek kemanfaatan rata-rata presentase 4,57 masing-masing memperoleh katagori sangat baik.

\section{Tahap Implementasi}

Produk yang telah melewati tahap uji coba kemudian diimplementasikan pada kegiatan pembelajaran. Kelompok siswa yang diberi perlakuan menggunakan multimedia pembelajaran interaktif yaitu siswa kelas XI MM-3 (kelas eksperimen). Sedangkan kelompok siswa yang dijadikan kelas pembanding (kelas kontrol) adalah siswa kelas XI MM-2 yang tidak menggunakan multimedia pembelajaran interaktif dan hanya menggunakan Buku teks mata pelajaran PCD dan media gambar pada saat kegiatan pembelajaran berlangsung.

Analisis butir soal mengambil data dari hasil yang diujikan pada kelas XI MM-2. Jumlah soal yang diujikan adalah 35 butir soal. Dari proses analisis butir soal diperoleh data bahwa 9 soal tidak valid. Butir soal yang valid memiliki indek kesukaran yang mudah, sedang dan sukar. Terdiri dari 21 soal Mudah, 11 soal sedang, dan 3 soal sukar. Dengan Daya pembeda baik dan sangat baik. Koefisien reliabilitas Alpha adalah 0,60 yang berarti reliabilitas soal baik.

Sebelum dilakukan uji rata-rata dua sampel yang saling berhubungan harus terlebih dahulu dilakukan uji prasyarat data yaitu uji normalitas dan uji homogenitas. Apabila data sudah memenuhi prasyarat maka selanjutnya dapat dilakukan uji dua rata-rata mengugunakan uji-t.

Uji normalitas bertujuan untuk mengetahui apakah variansi kelas eksperimen dan kelas kontrol berdistribusi normal atau tidak. Uji normalitas terhadap kelas ekperimen (XI MM-3) dan kelas kontrol (XI MM-2) dilakukan dengan menggunakan uji Liliefors. Adapun hasil perhitungan uji normalitas dengan taraf signifikansi $5 \%$ disajikan dalam tabel berikut:

Tabel 4. Tabel Perhitungan Uji Liliefors

\begin{tabular}{cccccrc}
\hline No & Kelompok & $\mathbf{N}$ & Lobs & Ltabel & Keputusan uji & Ket. \\
\hline 1 & Eksperimen & 34 & 0,12 & 0,150 & $H_{0}$ diterima & Normal \\
2 & Kontrol & 34 & 0,14 & 0,152 & $H_{0}$ diterima & Normal
\end{tabular}


Berdasarkan diatas dapat disimpulkan bahwa kelas eksperimen dan kelas kontrol memiliki data yang berdistribusi normal. Untuk perhitungan yang lebih lengkap dapat dilihat pada lampiran.

Uji homogenitas dalam penelitian ini menggunakan excel secara cepat dengan mengambil nilai pretest sebagai data awal untuk melakukan perhitungan. Uji Homogenitas variansi dengan 2 populasi (uji-F) dengan hasil yang diperoleh sebagai berikut: nilai $F_{\text {hitung }}=1,65$ dan nilai $F_{\text {tabel }}(F$ Critical one-tail) $=1,78$. Dengan ketentuan, jika $F_{\text {hitung }}<F_{\text {tabel }}$ maka Ho diterima. Jadi nilai 1,65 $<1,78$, berdasarkan perhitungan tersebut menerangkan jika keputusan uji $H_{0}$ diterima, kemudian dapat disimpulkan bahwa variansi kedua populasi yang sama atau homogen.

\section{Tahap Evaluasi (Uji Efektifitas Produk)}

Produk yang telah melewati tahap uji coba kemudian diimplementasikan pada kegiatan pembelajaran. Kelompok siswa yang diberi perlakuan menggunakan multimedia pembelajaran interaktif yaitu siswa kelas XI MM-3 (kelas eksperimen). Sedangkan kelompok siswa yang dijadikan kelas pembanding (kelas kontrol) adalah siswa kelas XI MM-2 yang tidak menggunakan multimedia pembelajaran interaktif dan hanya menggunakan Buku teks mata pelajaran PCD dan media gambar pada saat kegiatan pembelajaran berlangsung.

Sebelum menjadi produk akhir, multimedia multimedia pembelajaran interaktif pada mata pelajaran PCD kelas XI Multimedia terlebih dahalu dilakukan uji kelayakan dan efektivitas produk. Hal ini dilakukan untuk mendapatkan produk yang layak dan berkualitas dari segi isi materi dan media itu sendiri. Setelah produk dinyatakan layak, maka media pembelajaran ini dapat digunakan dalam pembelajaran PCD selanjutnya. Analisis kelayakan produk diperoleh dari data hasil pengisisan angket/lembar evaluasi dari ahli materi, ahli media, dan angket uji coba produk pada siswa, sedangkan efektivitas produk diperoleh dari hasil tes prestasi siswa.

Soal yang diujikan perlu dianalisis untuk mengetahui daya pembeda dan koefisien Alpha soal. Hasil pengujian dengan menggunakan software Microsoft Exel menunjukkan bahwa semua butir soal yang memiliki nilai koefisien Biser (daya pembeda) diatas 0.3 yang bearti soal diterima. Pengujian daya pembeda bertujuan untuk melihat kemampuan butir soal dalam membedakan antara peserta didik yang berkemampuan tinggi dengan peserta didik yang berkemampuan rendah. Semakin tinggi indeks daya pembeda soal berarti semakin mampu soal yang bersangkutan membedakan siswa yang telah memahami materi dengan siswa yang belum memahami materi.

Koefisien reliabilitas Alpha yang dicapai pada analisis butir soal ini yaitu 0.866 yang berarti soal reliabel. Sekaran (2006) membagi 0.8 - 1.0 maka reliabilitas soal baik. Semakin tinggi koefisien korelasi antara hasil ukur dari dua tes yang paralel, berarti konsistensi diantara keduanya semakin baik dan kedua alat ukur itu disebut sebagai alat ukur yang reliabel. Sebaliknya apabila korelasi antara hasil dari dua alat ukur yang paralel ternyata tidak tinggi maka disimpulkan bahwa reliabilitasnya rendah. Uji kelayakan multimedia pembelajaran interaktif pada mata pelajaran PCD untuk kelas XI Multimedia dapat dilihat dari hasil validasi ahli media dan ahli materi.

Hasil uji efektivitas dengan menggunakan Uji t berpasangan memperoleh hasil bahwa DK $=\{t \mid t \leq$ $-\mathrm{t}_{0.025 ; 33}=-2,03$ atau $\left.\mathrm{t} \geq \mathrm{t}_{0.025 ; 33}=2,03\right\}$ dan thitung $=-7,29$. Dan diketahui bahwa nilai Sig. (2-tailed) $=$ $0.000<0.05$, maka dapat disimpulkan bahwa kedua kelompok memiliki prestasi yang tidak sama. Kelas eksperimen memiliki rata-rata 85,41 sedangkan kelas kontrol memiliki rata-rata 71,29 . Berdasarkan data tersebut dapat disimpulkan bahwa penggunaan MPI pada mata pelajaran pengolahan citra digital dapat meningkatkan prestasi belajar siswa, karena diketahui siswa yang menggunakan multimedia 
pembelajaran interaktif pada mata pelajaran PCD lebih baik dibanding siswa yang hanya menggunakan buku pegangan siswa / paket.

Berdasarkan hasil pengembangan dapat diketahui bahwa produk multimedia pembelajaran interaktif pada mata pelajaran pengolahan citra digital untuk kelas XI Multimedia yang dikembangkan sesuai dengan model Analyze, Design, Development, Implementation, Evaluation (ADDIE). Produk yang ada bisa dikatakan layak dan bisa digunakan di dalam proses pembelajaran.

\section{Keefektifan Produk Berdasarkan Validasi Produk MPI}

Berdasarkan pada data hasil pengujian produk multimedia pembelajaran interaktif oleh beberapa ahli materi dikatakan valid dan bisa diujikan untuk menilai kelayakannya di dalam proses pembelajaran. Rata-rata penilaian ahli materi dari aspek pembelajaran sesuai dengan tujuan pembelajaran mendapat penilaian 4,39 kategori sangat baik. Hal ini diartikan bahwa program yang dibuat telah sesuai dengan tujuan yang akan dicapai. Ini sesuai dengan teori menurut Rahman \& Amri (2013) menyebutkan bahwa prinsip-prinsip pemilihan media pembelajaran adalah media yang dipilih harus sesuai dengan tujuan dan materi pembelajaran, metode mengajar yang digunakan serta karakteristik siswa yang belajar (tingkat pengetahuan siswa, bahasa siswa dan jumlah siswa yang belajar).

Aspek materi mendapat nilai rata-rata 4,63 dinyatakan dengan katagori sangat baik. Sesuai dengan teori yang dikemukakan oleh Daryanto (2010:56) bahwa materi pembelajaran yang terkandung didalamnya harus sesuai dengan kurikulum dan mengandung banyak manfaat. Ini dapat diartikan materi yang tersaji sudah jelas dan tepat sesuai dengan apa yang diajarkan oleh guru mata pelajaran. Kesesuaian soal dengan materi dinyatakan sangat baik sesuai dengan aspek desain pembelajaran pada komponen inti dalam pengembangan media pembelajaran yang dinyatakan Pustekom (2008:16) yaitu latihan, tes dan umpan balik yang korektif.

Berdasarkan pada hasil pengujian produk mulitmedia interaktif oleh ahli media, hasil nilai total rata-rata dikatakan valid. Aspek navigasi mendapatkan rata-rata 4,83 dengan kategori sangat baik. Hal ini sesuai dengan teori dari Munadi (2013) memberikan penjelasan bahwa program multimedia ini diprogram atau dirancang untuk dipakai oleh siswa secara invidual (belajar mandiri). Saat siswa mengaplikasikan program ini, dia diajak untuk terlibat secara auditif, visual, dan kinetik, sehingga dengan keterlibatan ini dimungkinkan informasi atau pesannya mudah dimengerti. Selain itu teori yang dikemukakan oleh Thorn (1995), bahwa salah satu kriteria dalam memilih multimedia interaktif adalah kemudahan navigasi, sebuah program harus dirancang sederhana sehingga pembelajar tidak perlu belajar komputer terlebih dahulu. Aspek tampilan mendapatkan rata-rata 4,30 dengan katagori sangat baik. Hal ini sesuai dengan teori dari Sadiman (2011) bahwa dalam pengembangan media harus diperhatikan karekteristik pengguna dalam mengembangkan media karena dalam mengembangkan media untuk jenjang tingkat sekolah berbeda-beda.

Aspek daya tahan produk dengan kategori sangat baik dengan rata-rata 4,63 . Hal ini sesuai dengan teori dari Sadiman (2009) menyatakan bahwa, "Media adalah segala sesuatu yang dapat digunakan untuk menyalurkan pesan dari pengirim ke penerima sehingga dapat merangsang pikiran, perasaan perhatian dan minat serta perhatian siswa sedemikian rupa sehingga proses belajar terjadi". Pengertian tersebut dapat disimpulkan bahwa media adalah semua objek yang digunakan sebagai perantara untuk menyampaikan pesan atau informasi agar pesan tersebut dapat diterima dengan baik oleh penerima pesan. Media pembelajaran berfungsi mengatasi keterbatasan pengalaman siswa dan keterbatasan ruang kelas, memungkinkan interaksi langsung antara siswa dengan lingkungan, dan membangkitkan motivasi siswa (Kustiono, 2010). 
Berdasarkan penilaian multimedia pembelajaran interaktif menurut siswa dari aspek motivasi memperoleh nilai total 4,6 dengan katagori sangat baik dan aspek kemenarikan dengan nilai rata-rata 4,69 dengan kategori sangat baik. Aspek kemudahan peserta belajar dalam belajar individual mendapat nilai rata-rata 4,57. Berdasarkan hasil yang diperoleh pada data penelitian tersebut sesuai dengan teori menurut Hamalik (1986) dalam Kustandi dan Suctipto (2011), pemakaian media pembelajaran dalam proses belajar mengajar dapat membangkitkan keinginan dan minat yang baru, membangkitkan motivasi dan rangsangan kegiatan belajar, dan bahkan membawa pengaruh-pengaruh psikologis terhadap siswa. Penggunaan media pembelajaran pada tahap orientasi pembelajaran akan sangat membantu proses pembelajaran dan penyampaian informasi pada saat itu juga. Media pembelajaran juga dapat membantu siswa meningkatkan pemahaman, menyajikan data dengan menarik dan terpercaya, memudahkan penafsiran data, memadatkan informasi, serta membangkitkan motivasi dan minat siswa dalam belajar.

Aspek kemanfaatan dengan rata-rata total 4,57 katagori sangat baik, didukung kuat dengan teori program dapat dimanfaatkan kembali untuk mengembangakan multimedia pembelajaran lain (reusabilitas) (Pustekom 2008).

\section{Keefektifan Program Multimedia Pembelajaran Interaktif Berdasarkan Ketuntasan Siswa}

Hasil dari perhitungan uji t berpasangan bahwa pada $a=5 \%$ dengan $D K=\left\{t \mid t \leq-t_{0.025 ; 33}=-2,03\right.$ atau $\left.\mathrm{t} \geq \mathrm{t}_{0.025 ; 33}=2,03\right\}$ dan thitung $=-7,29$, maka $-\mathrm{t}_{\text {hitung }}=-7.297 \geq-\mathrm{t}_{\text {tabel }}=-2.034$. Dan diperoleh nilai Sig. (2-tailed $)=0.000<0.05$, maka dapat disimpulkan bahwa kedua kelompok memiliki prestasi yang tidak sama. Kelas eksperimen memiliki rata-rata 85,41 sedangkan kelas kontrol memiliki rata-rata 71,29 .

Berdasarkan data dan deskripsi diatas disimpulkan bahwa program multimedia pembelajaran interaktif macam-macam jaringan komputer efektif digunakan dalam proses pembelajaran karena setelah menggunakan media yang baru hasil belajar siswa meningkat. Hal ini sesuai dengan pernyataan dari Sugiyono (2010) bahwa indikator keefektifan metode mengajar baru adalah kecepatan pemahaman murid pada pelajaran lebih tinggi, murid bertambah kreatif, dan hasil belajar meningkat. Diperkuat juga dengan teori menurut Arsyad (2011) yang mengemukakan bahwa media pembelajaran dapat memperjelas penyajian pesan dan informasi sehingga dapat memperlancar serta meningkatkan proses dan hasil belajar.

\section{Keefektifan Multimedia Pembelajaran Interaktif Berdasarkan Pengamatan}

Pengamatan dalam pembelajaran dilakukan untuk mengetahui bagaimana respon siswa sebagai objek dalam mempelajarai multimedia pembelajaran interaktif. Proses pengamatan dilakukan selama dua kali sebelum dan sesuadah menggunakan multimedia pembelajaran interaktif. Berdasarkan pengamatan yang dilakukan sebelum menggunakan multimedia pembelajaran interaktif pembelajaran kurang kondusif dimana tidak adanya pemusatan perhatian siswa.

Hal ini dilihat dari siswa yang banyak berbicara di kelas saat guru mengajar. Siswa malas atau tidak semangat dalam mengikuti pelajaran yang bersifat teori. Setelah menggunakan multimedia pembelajaran interaktif siswa semangat dalam belajar. Hal ini sesuai dengan pendapat Sudjana \& Rifai (20011) bahwa salah satu manfaat menggunakan multimedia pembelajaran yaitu pengajaran akan lebih menarik perhatian siswa sehingga dapat menumbuhkan motivasi belajar. Siswa tenang dan tidak berbicara dalam proses belajar menggunakan multimedia pembelajaran interaktif. Sehingga dapat disimpulkan terdapat perbedaan perilaku siswa dalam belajar sebelum dan sesudah menggunakan multimedia pembelajaran interaktif. 
Penemuan penelitian ini diperkuat dengan penelitian terlebih dahulu yang dilakukan oleh Van der Westhuizen, Nel and Richter (2012). Dengan judul "An Analysisi of Students' Academic Performance When Integrating DVD Technology in Geography Teaching and Learning", tujuan dari penelitian ini adalah untuk mengetahui pengaruh pengintegrasian media DVD sebagai ICT untuk guru geografi di pedesaan dan daerah berkembang, penelitian ini dilakukan selama tiga tahun. Mencoba untuk menentukan apakah integrasi DVD efektif dapat mendukung pembelajaran dan belajar siswa guru geografi dalam lingkungan belajar yang berpusat pada peserta didik.

Hasil dari penelitian ini menunjukan bahwa siswa tersebut menunjukkan hasil positif mengenai integrasi DVD dalam geografi belajar mengajar. Ini sesuai dengan prinsip-prinsip pembelajaran OBE (outcome based eduction) mengajar berpusat pada pelajar dan serta prinsip-prinsip tentang bagaimana mengintegrasikan TIK secara efektif dalam proses belajar mengajar.

\section{KESIMPULAN}

Berdasarkan hasil analisis data dan pembahasan, simpulan yang dapat diambil dari penelitian ini yaitu, dengan Multimedia Pembelajaran Interaktif pada mata pelajaran pengolahan citra digital terbukti dapat membantu guru sebagai alat bantu dalam memperjelas penyajian materi pelajaran sehingga dapat memotivasi siswa dan meningkatkan hasil belajar siswa, terbukti dari hasil validasi oleh ahli media dan ahli materi serta hasil uji coba pemakaian terhadap siswa. Serta Multimedia Pembelajaran Interaktif dapat meningkatkan keefektifan terhadap hasil belajar siswa, memotivasi siswa, serta menciptakan interaksi langsung antara guru dengan siswa, sehingga pembelajaran lebih efektif, efisien dan menarik.

\section{SARAN- SARAN}

Berikut adalah pemaparan saran pemanfaatan produk media pembelajaran interaktif yang dikembangkan berdasarkan hasil penelitian yang telah disajikan:

1. Sebagai bahan pertimbangan, guru hendaknya menggunakan Multimedia Pembelajaran Interaktif pada mata pelajaran pengolahan citra digital untuk kelas XI Multimedia, sehingga pembelajaran lebih interaktif, serta dapat meningkatkan hasil belajar siswa di sekolah. Perlu dilakukan penelitian lebih lanjut dengan mengambil materi yang lain sehingga diperoleh hasil yang lebih menyakinkan tentang keefektifan Multimedia Pembelajaran Interaktif pada mata pelajaran pengolahan citra digital untuk kelas XI Multimedia.

2. Proses validasi yang berlapis akan membuat produk semakin sempurna dan mengurangi dampak kesalahan yang berlanjut atau yang berkepanjangan.

3. Produk yang dikembangkan adalah produk MPI untuk pembelajaran klasikal. Agar dapat dimanfaatkan untuk pembelajaran mandiri supaya lebih optimal, perlu adanya pengembangan lebih lanjut agar dapat dimanfaatkan seluas mungkin dan dapat dijalankan pada aplikasi smartphone sebagai mobile-learning.

4. Bagi Sekolah, hendaknya sekolah menginspirasi guru-guru dalam pengembangan media pembelajaran interaktif. 
5. Kepala Sekolah hendaknya selalu aktif, mendorong guru-guru untuk melaksanakan pembelajaran yang kreatif dan inofatif salah satunya dengan multimedia pembelajaran interaktif.

6. Bagi Guru. Diharapkan guru membuat dan mengembangkan multimedia pembelajaran interaktif pembelajaran tidak hanya dalam pembelajaran pengolahan citra digital tapi juga pada materi dan mata pelajaran yang lainnya.

7. Bagi siswa. Siswa hendaknya dapat berperan aktif dengan menyampaikan ide dan saran pada proses pembelajaran, sehingga nantinya memperoleh hasil belajar yang optimal. Siswa dapat menggunakan MPI pembelajaran pengolahan citra digital secara klasikal dan mandiri.

\section{DAFTAR PUSTAKA}

Anitah, S. (2009). Media Pembelajaran. Surakarta: UNS Press.

Arsyad, A. (2011). Media Pembelajaran. Jakarta: Raja Grafindo Persada.

Borg, W.R. \& Gall, M.D. (2007). Educational Research: An Introduction. New York: Longman

Daryanto, (2010). Media Pembelajaran. Yogyakarta: Gava Media.

Kustiono. (2010). Media Pembelajaran. Semarang: UNNES Press.

Munandi, Y. (2013). Media Pembelajaran Sebuah Pendekatan Baru. Jakarta Selatan: Referensi.

Pustekom. (2008). 7 Langkah Muda Membuat Multimedia Pembelajaran. Diakses 26 April 2017.

Rahman, M. \& Amri, S. (2013). Strategi dan Desain Pengembangan Sistem Pembelajaran. Jakarta: Prestasi Pustakaraya.

Sadiman, A. (2009). Media Pendidikan. Jakarta: PT. Raja Grafindo Persada.

Sadiman, A. (2011). Media Pendidikan. Jakarta: PT. Raja Grafindo Persada.

Seels, B., \& Richey, R. C. (1994). Teknologi Pembelajaran, Definisi dan Kawasannya. Jakarta: Universitas Negeri Jakarta

Sudjana \& Rifa'l, A. (2011). Teknologi Pengajaran. Bandung: Sinar Baru Algensindo.

Sugiyono. (2008). Metode Penelitian Pendidikan PendekatanKuantitatif, Kuliatitatif, R\&D. Bandung: Alfabeta.

Sugiyono. (2010). Metode Penelitian Pendidikan PendekatanKuantitatif, Kuliatitatif, R\&D. Bandung: Alfabeta.

Susilana, R. \& Riyana, C. (2008). Media Pembelajaran. Bandung: Jurusan KURTEKPEND FIP UPI.

Sutopo, A. H. (2012). Teknologi Informasi dan Komunikasi dalam Pendidikan. Yogyakarta: Graha Ilmu. 
Van der Westhuizen, C.P., Nel, C., \& Richter, B. W. (2012). An Analysisi of Students' Academic Performance When Integrating DVD Technology in Geography Teaching and Learning. Educational Technology \&Society, 15(3), pp. 190-201

Warsita, B. (2008). Teknologi Pembelajaran, Landasan dan Aplikasinya. Jakarta: Rineka Cipta. 